\title{
English Language Teachers' Attitudes Towards Critical Thinking within Moroccan High Schools
}

\section{Youssouf Laabidi}

Faculty of Educational Sciences, Madinat Al Irfane, Rabat, Morocco [laabidi.youssef@hotmail.fr]

Received: 25/05/2021
Abstract: This study addresses the restricted attention of critical thinking in the Teaching of English as a Foreign
Language (TEFL) in Moroccan high schools, which is one of the new issues investigated in recent times. Many
students could not think critically since their instructors could not implement critical thinking into their
instructional practices every day. The primary objective of this inquiry is to examine teachers' attitude towards
the use of critical thinking in the classroom. In this paper, the questionnaire was used to address only English
language high school teachers. Descriptive statistical analysis of means, standard deviations, and percentages
were used. The results showed that teachers held a positive attitude towards the use of critical thinking in the
classroom. Therefore, they need not hesitate to introduce it in their teaching. Our findings strongly indicate that
having an understanding of what really happened in the classroom will surely help shape the development of
critical thinking in education. This suggests that further study could be carried to determine teachers' level of use
of critical thinking in Moroccan high schools.

Keywords: attitude; critical thinking; high school; teachers

\section{Introduction}

Nearly all instructors in all parts of the world used textbooks as their primary resource, and the major objective in several classrooms was making sure that learners memorized facts (Zohar \& Dori, 2003). The role of educators was perceived by many educators as the sender of these facts to their students (Zohar \& Dori, 2003; Ibrahim \& Ismail, 2021). However, Hay (2001) contended that the requirements of this society have altered dramatically, and schools have not kept up with these adjustments. In other words, the common burden in education is that we are not adapting to the dynamic world we live in, and our learners are quitting schools unaware of what lies in front of them (Wagner, 2008; Benattabou, 2020). Some teachers employ a lecture format in their classrooms, but this famous approach does not stimulate critical thinking by learners (Duron et al., 2006).

It is worth stating that critical thinking possesses a significant role in contemporary education, aiming to supply an atmosphere where learners build their personal knowledge and take charge of their own learning (Khatib, Marefat, \& Ahmadi, 2012). Critical thinking is regarded an effective means and essential skill to survive and attain good outcomes in the complicated 21st-century world (Pellegrino \& Hilton, 2012). Russell (1956) noted that "critical thinking is the process of examining concrete verbal materials in the light of related objective evidence, comparing the object or statement with some norm or standard, and concluding or acting upon the judgement made" (p.301). Russell provided another definition of critical thinking. He stated that critical thinking "is the process of evaluation or categorization in terms of some previously accepted standards". This seems to involve attitude, plus knowledge of facts, plus some thinking skills (Russell,1960). 
In Morocco, the field of education gains a huge body of financing, which reveals the special status and attention compared to other domains of the government (Hamdy, 2007). In higher education, for instance, Chouari (2016) mentioned that the Ministry of Higher Education launched an educational reform in the Fall Semester of 2014 and some universities integrated critical thinking in the curriculum. The author further stated that the Faculty of Arts and Humanities in Meknes (University of Moulay Ismail) introduced critical thinking as an independent course in the Department of English Studies.

The integration of critical thinking in the classroom increases the value of education by supporting instructors to carry out their work and by encouraging students to learn effectively. It can affect the way learners are taught and how they learn. Indeed, this would get students ready for lifelong learning as well as to ameliorate the value of learning. It is hoped that this study will lay the ground for further research on critical thinking and will contribute to the literature on critical thinking integration in Moroccan high schools. It is argued that this type of research is relevant for teachers and students in that the results could be used to ameliorate instructors' teaching practices and students learning. In the same way, this research paper sought to contribute to the knowledge base on critical thinking in Morocco by trying to explore teachers' practice of this essential notion in their classes.

\section{Literature Review}

\subsection{Definition of Attitude}

Before going into a deep discussion of teachers' attitude towards the use of critical thinking, it is necessary to provide some definitions of the term, attitude. In fact, attitude is considered as an important notion to comprehend human behavior and is recognized as a mental state that involves beliefs and feelings (Latchanna \& Dagnew, 2009). Eagly and Chaiken (1993) defined attitude as "a psychological tendency that is expressed by evaluating a particular entity with some degree of favor or disfavor" (p.1).

Attitude is described as a positive or a negative feeling connected with accomplishing a particular behavior (Ajzen \& Fishbein,1980). Ajzen and Fishbein (1980) further stated that a person will have a positive attitude if he or she admits that the achievement of the behavior will guide to mostly positive conclusions and vice-versa. An attitude improves based on individuals' beliefs toward a situation or an object (Godin, Belanger-Gravel, Eccles, \& Grimshaw, 2008). Reid (2003) reports that attitudes "express our evaluation of something or someone. They may be based on our knowledge, our feelings and our behaviour and they may influence future behaviour." (p.32). In other words, Reid (2006) confirmed that attitude involves three dimensions: 1) Cognitive; 2) Affective, and 3) Behavioural. The cognitive element means the ideas or beliefs an individual possesses about an attitudinal object. The affective component refers to the emotions and feelings that affect the ideas. The third component, which is the behavioural dimension, involves the acts or behaviours that a person performs. In the same line of thought McGuire (1985) stressed that attitudes are multi-dimensional and are made up of cognitive, affective and behavioural aspects. Similarly, Ajzen and Fishbein (1980) displayed that attitude comprises three components: affect, cognition, and behavior. Indeed, Ajzen and Fishbein (1980) said that "a complete description of attitude requires that all three components be assessed by obtaining measures of all the three response classes" (1980, p. 20).

\subsection{Teachers' attitudes toward critical thinking}

The instructor factors that impact success are instructor attitude toward change, instructor pedagogical knowledge, and instructor attitude toward school as a learning organization (Sandy, 2010). Teachers' attitude toward critical thinking is an aspect that can influence implementing critical thinking 
practices in the classroom. Halpern (1989) stressed the significance of a critical thinking attitude and makes little difference between critical thinking and the critical thinker. "Good thinkers are motivated and willing to exert the conscious effort needed to work in a painful manner, to check for accuracy, to gather information, and to persist when the solution isn't obvious and/or requires several steps" (p.29). "Whenever we think (or reason), we think for a purpose within a point of view based on assumptions leading to implications and consequences. We use concepts, ideas and theories to interpret data, facts, and experiences in order to answer questions, solve problems, and resolve issues" (Paul \& Elder, 2009, p. 5).

Educators' attitudes toward teaching critical thinking skills and their lack of satisfactory recognition of thinking skills can be a constraint to their ability to boost the learning process (Kowalczyk et al., 2012). According to Nelson (2005), a critical thinking attitude is the basis for critical thinking that would be a reflection of an individual's engagement in a purposeful task. It must be noted here that several distinguished researchers confirm that educators' attitudes affect their behaviors in the learning environment. Horwitz (1989), for instance, affirmed that "we (educators) think of our classrooms as 'communication-centred' or 'grammar-focused', as dominated by 'teacher talk', while our students are more likely to think of their course as 'hard' or 'easy' and of their instructors as 'strict' or 'lenient" (p. 61). Therefore, educators are recommended to abandon the attitude that students are not able to study unless an instructor teaches the whole material (Choy \& Cheah, 2009). At this point, it is worth stating that Tarman (2012) confirmed that teachers' prior attitudes can be changed by equipping them with professional developmental programs.

Current works revealed that what instructors assume about critical thinking has a clear influence on how they communicate with their learners and organize classroom exercises (Qing et al., 2012). Mok (2010) stressed the importance of studies in the field of critical thinking and language learning, as the author proposed: "the need for further investigation of critical thinking into teachers' perceptions and their impact on teacher classroom practices" (pp. 277-278). In this atmosphere, in a qualitative investigation by Alazzi (2008), the researcher interviewed high school social studies teachers concerning their attitudes on teaching critical thinking skills in their classes. The findings showed that Jordanian educators displayed an immature understanding of the definition and teaching strategies of critical thinking. Stapleton (2011) conducted a survey of attitudes toward critical thinking among Hong Kong secondary school instructors. Indeed, high school teachers were interviewed concerning their attitudes about the notion of critical thinking. The results showed that the participants revealed a strong approval for the implementation of critical thinking in the curriculum while indicating a leaning for training in terms of how to teach critical thinking.

\section{Methodology}

\subsection{Research Design}

This research employed the quantitative research design. It measures variables in a quantifiable way using percentages graphs and tables of data. Creswell (2012) said that "quantitative data, such as scores on instruments, yield specific numbers that can be statistically analyzed, can produce results to assess the frequency and magnitude of trends, and can provide useful information if you need to describe trends about a large number of people." (p.535).

\subsection{Participants}

The population for this research is composed of Moroccan English language high school teachers. The population consisted of both males and females. To get access to many teachers and reach high 
response rates from participants, the survey questionnaire was distributed and sent via emails to various teachers.

\subsection{Research Instrument}

The instrument that was used in this research to gather data is the questionnaire. Actually, respondents were asked to "answer the questions thus providing the researcher with data that can be analysed and interpreted" (Oates, 2006, p219). According to Kumar (2005), "in questionnaires respondents read the questions, interpret what is expected and then write down the answers" (P. 33). A survey questionnaire was designed in this research to investigate teachers' practice of critical thinking in Moroccan high schools by tackling primarly teachers' attitudes towards critical thinking.

The first part of the questionnire addressed the demographic data of the participants such as gender, age, educational level, and teaching experience. It also collected data about teachers' training in critical thinking. The demographic data was employed in this study to gather information about the participants and to understand them.

\subsection{Process}

The population of this investigation is sampled using convenience sampling methods. The data was gathered using both a paper-based instrument and an online questionnaire. The copies of the questionnaire were delivered in person to avoid a low response rate. The free online survey tool of Google Forms was used to design the online version of the questionnaire. The use of the online version of the survey questionnaire was useful for the participants and the researcher. In this research, the mailed questionnaire was a convenient way to reach a geographically dispersed sample of a population.

The online version of the survey questionnaire was uploaded to the Internet with the site address as an online submission form and made available for teachers to access and complete. Additionally, the questionnaire link was e-mailed to individual high school teachers. In fact, one week after the first distribution, an e-mail reminder was sent out reminding those who might have forgotten to complete the questionnaire. A total of 208 responses were completed using the online version of the survey questionnaire, whereas 215 were completed using the paper-based version of the survey.

\subsection{Data Analysis}

Descriptive and inferential statistics were used in this research to analyze the quantitative data. The data was analyzed using the Statistical Package for Social Sciences (SPSS) to obtain research statistics. After receiving the completed surveys from 423 respondents in the study, the collected information was uploaded to SPSS, version 20. The data were analysed using frequencies, percentages, means, and standard deviations. Twenty items were constructed to discover teachers attitudes towards the implementation of critical thinking in their classes.

\section{Results}

This section details the findings that tackle the research question explored in the present study. Descriptive statistics such as means, standard deviations, and percentages were used. 


\subsection{Participants' Background Information}

\subsubsection{Gender}

A total of 423 English language high school teachers responded to the questionnaire. The gender distribution of the sample shows that of the 423 respondents, $62,65 \%$ were male $(\mathrm{N}=265)$ and $37,35 \%$ were female $(\mathrm{N}=158)$. As indicated in Figure 1, there were more male teachers than female teachers.

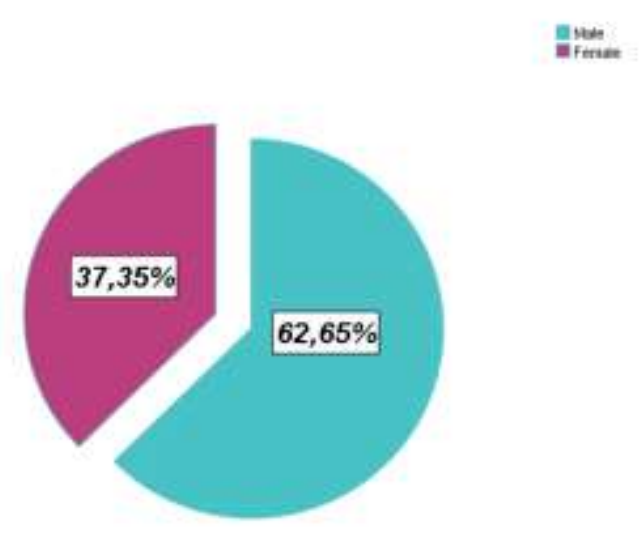

Figure 1. Gender distribution of the participants

\subsubsection{Age}

Figure 2 below indicates clearly the different age groups of the respondents who took part in this study. The age of the respondents ranged from 20 to 60 years or above. The highest percentage of participants $(34,52 \%)$ was in the age range of $30-39$ years $(\mathrm{N}=146)$ followed by $(21,28 \%)$ in the age range of 50-59 years $(\mathrm{N}=90)$. The third largest age group of teachers fell between 40 and 49 years, representing $(17,73 \%)$ of the participants $(\mathrm{N}=75)$, and only $(16,08 \%)$ was in the range of 20-29 years $(\mathrm{N}=68)$. The lowest percentage of participants $(10,40 \%)$ was at the age of 60 years or above $(\mathrm{N}=44)$.

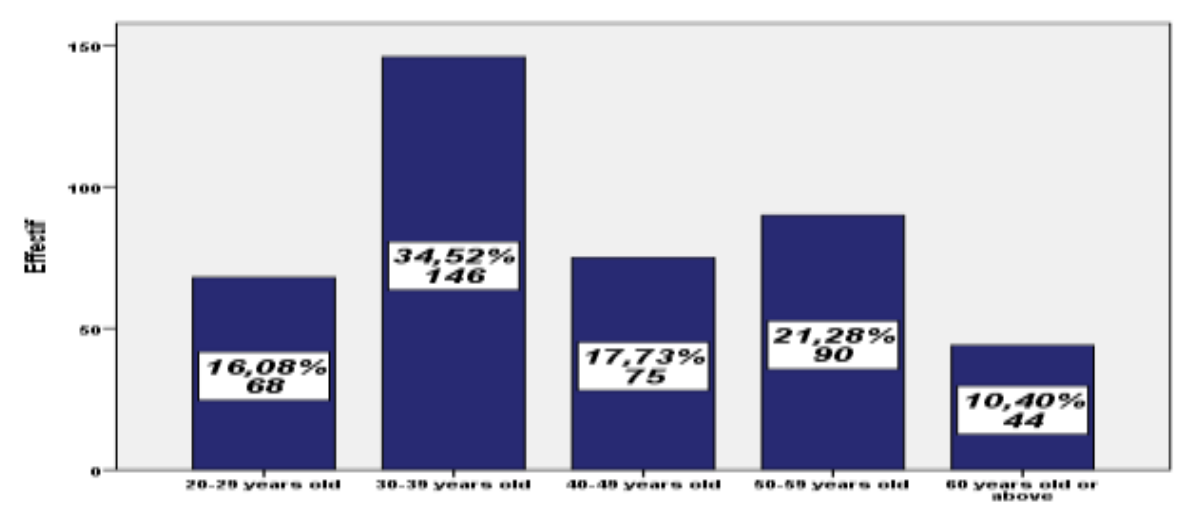

Figure 2. Age distribution of the participants 


\subsubsection{Educational Background}

As far as educational background, the majority of the respondents ( $\mathrm{N}=273)$ hold a master's degree, representing $(64,54 \%)$ of the participants. Besides, $(\mathrm{N}=138)$ of the participants hold a bachelor's degree that mirrors $(32,62 \%)$ of the respondents. Another 12 English language teachers hold a doctorate degree which refers to $2,84 \%$ of the sample. The educational background of the participants is shown in Figure 3.

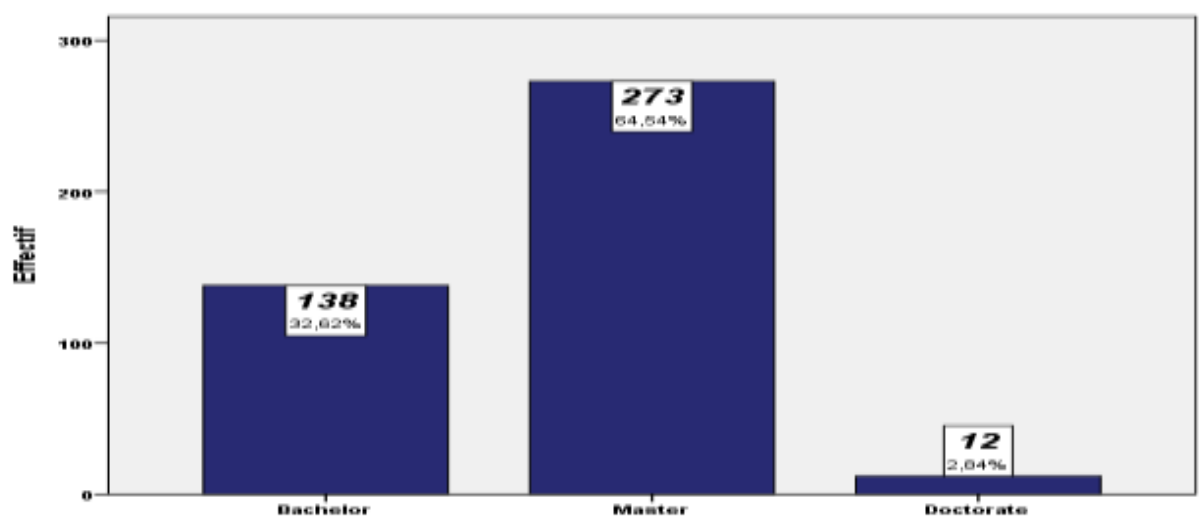

Figure 3. Response frequencies for participants' educational background

\subsubsection{Teaching Experience}

The teaching experience of the respondents ranged from less than 5 to more than 25 years. The highest percentage of respondents $(24,59 \%)$ was in the teaching experience range for more than 25 years $(\mathrm{N}=104)$. Besides, $(23,64 \%)$ of the participants were in the teaching experience range 5-10 years. Furthermore, $(13,71 \%)$ of the respondents had between 16 to 20 years of teaching experience, and $(13,48 \%)$ of the participants had less than five years of teaching experience. Another $(\mathrm{N}=55)$ English language teachers representing $(13 \%)$ of the research's respondents were in the teaching experience range 21-25 years. The remaining $(11,58 \%)$ of the participants had between 11 to 15 years of teaching experience. From the responses, it is possible to say that most English language teachers have high teaching experience displaying that they have been in the field of teaching for a long time. Figure 4 shows the teaching experience of the participants.

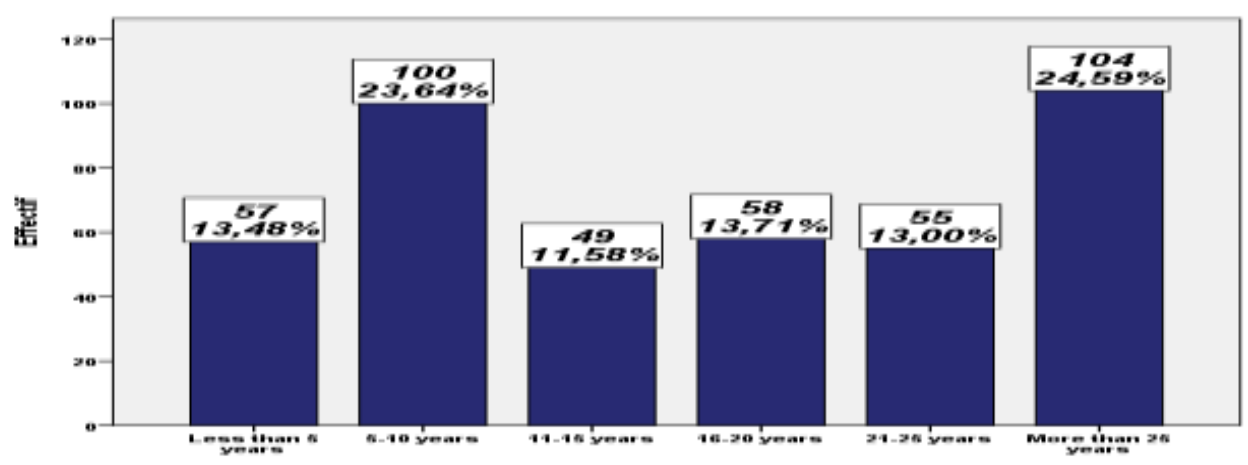

Figure 4. Response frequencies for participants' teaching experience 


\subsubsection{Training in Critical Thinking}

As seen in Figure 5, only 103 of the 423 participants received training in critical thinking. Indeed, most of the respondents $(75,65 \%)$ reported that they had no critical thinking training at all whereas only $(24,35 \%)$ of the participants declared that they obtained training in critical thinking.

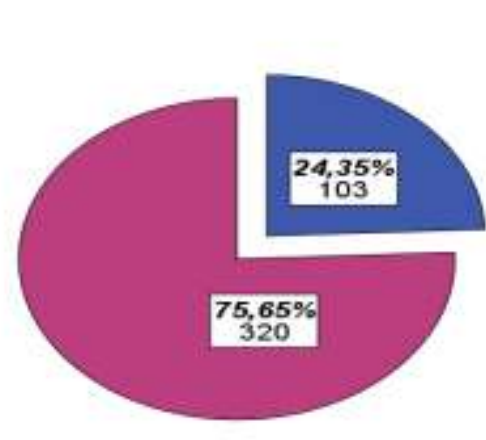

Figure 5. Response frequencies for participants' training in critical thinking

\subsection{Questionnaire Findings}

Participants were required to display the extent to which they agreed or disagreed with 20 statements concerned with attitude towards critical thinking. The items were based on a 5-point Likert scale in which: $1=$ Strongly disagree, $2=$ Disagree, $3=$ Neutral, 4=Agree, and 5=Strongly agree. In this respect, it is crucial to say that respondents who got high scores on each item implied that they have positive attitudes towards the use of critical thinking, whereas lower scores displayed negative attitudes. The results are reported using descriptive statistical analysis of means, standard deviations, and percentages. The second part (B) of the questionnaire contains 20 statements that are in two groups. The first group involves 14 statements related to teachers (Items 1 to 14), and the second group includes 6 statements concerned with students (items 15 to 20).

\subsubsection{Items related to teachers}

As shown in Table 1, 83\% of the respondents agreed or strongly agreed with the statement "implementing critical thinking in my teaching does not frighten me at any moment". This simply means that most teachers have a positive attitude toward critical thinking. Also, (67.9\%) agreed or strongly agreed with the statement "I feel confident to implement critical thinking in my lesson". Moreover, a large majority of respondents $93.2 \%$ agreed or strongly agreed with the statement "I believe that critical thinking allows individuals to organize work". This showed clearly that most teachers are conscious of the fact that critical thinking could make a difference in their teaching. This is supported by the finding which indicated that $(95 \%)$ of the respondents agreed or strongly agreed with the statement "using critical thinking in my instruction is beneficial". The same number of respondents $95 \%$ agreed or strongly agreed with the statement "I believe that critical thinking is the heart of the changes of the 21 st century". Additionally, almost all respondents $97.4 \%$ agreed or strongly agreed with the statement "I believe that future teachers must be prepared to be models of critical thinkers". In the light of information provided previously, (93.6\%) of respondents tended to disagree or strongly disagree with the following negative statement "I prefer to avoid using critical thinking in my lesson as much as I can". In response to another statement, "training in implementing critical 
thinking is a waste of time and effort for me", a large number of respondents (98.1\%) disagreed or strongly disagreed with it. Besides, (97.6\%) of respondents disagreed or strongly disagreed with the statement "I detest making use of critical thinking in my classroom".

\subsubsection{Items related to students}

Table 1 shows that $(86,1 \%)$ of respondents agreed or strongly agreed with the statement "I prefer to see every learner in my class employing critical thinking skills". A high percentage of respondents 96\% agreed or strongly agreed with the statement "I am convinced of the value of critical thinking in education". Besides, (97.6\%) of respondents agreed or strongly agreed with the statement "I think that critical thinking skills must be encouraged inside the classroom and outside its walls". Another significant finding is that a large number of respondents $97.2 \%$ agreed or strongly agreed with the statement "I believe that all learners should be taught to think critically".

Table 1. Response frequencies for teachers' attitudes towards critical thinking

\begin{tabular}{|c|c|c|c|c|c|c|}
\hline No. & Teachers' attitudes towards critical thinking & SD & $\mathbf{D}$ & $\mathbf{N}$ & $\mathbf{A}$ & $\mathbf{S A}$ \\
\hline 1 & $\begin{array}{l}\text { *I prefer to avoid using critical thinking in my lesson as much as I } \\
\text { can. }\end{array}$ & 38.5 & 55.1 & 4.7 & 1.0 & 0.7 \\
\hline 2 & $\begin{array}{l}\text { Implementing critical thinking in my teaching doesn't frighten me } \\
\text { at any moment. }\end{array}$ & 0.7 & 1.4 & 14.9 & 66.2 & 16.8 \\
\hline 3 & *Critical thinking activities make me feel nervous. & 17.7 & 48.9 & 29.6 & 3.3 & 0.5 \\
\hline 4 & *I enjoy traditional methods of the easy transfer of information. & 14.2 & 33.3 & 45.6 & 6.1 & 0.8 \\
\hline 5 & I feel confident to implement critical thinking in my lesson. & 0.0 & 2.1 & 30.0 & 58.9 & 9.0 \\
\hline 6 & I believe that critical thinking allows individuals to organize work. & 0.2 & 1.6 & 5.0 & 82.3 & 10.9 \\
\hline 7 & $\begin{array}{l}\text { I think that critical thinking is indispensable in the field of teacher } \\
\text { education. }\end{array}$ & 1.6 & 1.9 & 2.1 & 55.6 & 38.8 \\
\hline 8 & $\begin{array}{l}\text { *Training in implementing critical thinking is a waste of time and } \\
\text { effort for me. }\end{array}$ & 57.2 & 40.9 & 1.2 & 0.5 & 0.2 \\
\hline 9 & Using critical thinking in my instruction is beneficial. & 0.5 & 1.00 & 3.5 & 78.0 & 17.0 \\
\hline 10 & $\begin{array}{l}\text { *Discussing critical thinking integration with teachers is useless } \\
\text { for me. }\end{array}$ & 46.1 & 48.5 & 3.3 & 1.2 & 0.9 \\
\hline 11 & $\begin{array}{l}\text { I believe that critical thinking is the heart of the changes of the } 21 \text { st } \\
\text { century. }\end{array}$ & 0.2 & 1.5 & 3.3 & 70.7 & 24.3 \\
\hline 12 & *I have no intention to integrate critical thinking in my class. & 52.5 & 43.7 & 2.0 & 0.9 & 0.9 \\
\hline 13 & $\begin{array}{l}\text { I believe that future teachers must be prepared to be models of } \\
\text { critical thinkers. }\end{array}$ & 0.9 & 0.8 & 0.9 & 64.3 & 33.1 \\
\hline 14 & *I detest making use of critical thinking in my classroom. & 58.6 & 39.0 & 0.7 & 0.7 & 1.0 \\
\hline 15 & $\begin{array}{l}\text { I prefer to see every learner in my class employing critical thinking } \\
\text { skills. }\end{array}$ & 0.5 & 0.7 & 12.7 & 70.0 & 16.1 \\
\hline 16 & Critical thinking activities boost students' motivation. & 0.2 & 0.8 & 41.1 & 46.6 & 11.3 \\
\hline 17 & I encourage students to use critical thinking for solving problems. & 0.5 & 5.7 & 19.1 & 62.2 & 12.5 \\
\hline 18 & I am convinced of the value of critical thinking in education. & 0.2 & 0.7 & 3.1 & 64.3 & 31.7 \\
\hline 19 & $\begin{array}{l}\text { I think that critical thinking skills must be encouraged inside the } \\
\text { classroom and outside its walls. }\end{array}$ & 0.5 & 0.0 & 1.9 & 56.7 & 40.9 \\
\hline 20 & I believe that all learners should be taught to think critically. & 0.2 & 0.2 & 2.4 & 65.5 & 31.7 \\
\hline
\end{tabular}

Scale: $\mathrm{SD}=$ Strongly Disagree, $\mathrm{D}=$ Disagree, $\mathrm{N}=$ Neutral, $\mathrm{A}=$ Agree, $\mathrm{SA}=$ Strongly Agree Note: *negative items were reversed before scoring

To further explore teachers' attitudes towards the use of critical thinking in their classrooms, analysis of means and standard deviations was conducted. Table 2 reveals the means and standard deviations of all the statements related to teachers' attitudes towards critical thinking. Teachers' attitudes were represented by a mean score on a 5-point scale, where 5 (Strongly Agree) represents the maximum 
score of the scale and 1 (Strongly Disagree) represents the minimum score. Another way of expressing this point is that higher mean scores on each item indicated high positive attitudes, whereas lower mean scores showed negative attitudes (or low positive attitudes).

\subsubsection{Items related to teachers}

As depicted in Table 2, respondents strongly disagreed $(\mathrm{M}=4.54 ; \mathrm{SD}=0.57)$ with the negative statement "training in implementing critical thinking is a waste of time and effort for me". The second highest mean ( $\mathrm{M}=4.53 ; \mathrm{SD}=0.64)$ was recorded for the negative statement "I detest making use of critical thinking in my classroom". The third highest mean $(\mathrm{M}=4.45 ; \mathrm{SD}=0.67)$ was marked for the negative statement "I have no intention to integrate critical thinking in my class". Besides, with another high mean score of $(M=4.37 ; \mathrm{SD}=0.69)$, English teachers expressed their strong disagreement with the statement "discussing critical thinking integration with teachers is useless for me". The fifth highest mean $(\mathrm{M}=4.29 ; \mathrm{SD}=0.66)$ was recorded for the statement "I prefer to avoid using critical thinking in my lesson as much as I can".

Table 2. Means and standard deviations of teachers' attitudes towards critical thinking

\begin{tabular}{clcc}
\hline No. & Teachers' attitudes towards critical thinking & M & SD \\
\hline 1 & I prefer to avoid using critical thinking in my lesson as much as I can. & 4.29 & 0.66 \\
2 & Implementing critical thinking in my teaching doesn't frighten me at any moment. & 3.97 & 0.66 \\
3 & Critical thinking activities make me feel nervous. & 3.80 & 0.78 \\
4 & I enjoy traditional methods of the easy transfer of information. & 3.54 & 0.83 \\
5 & I feel confident to implement critical thinking in my lesson. & 3.75 & 0.64 \\
6 & I believe that critical thinking allows individuals to organize work. & 4.02 & 0.49 \\
7 & I think that critical thinking is indispensable in the field of teacher education. & 4.28 & 0.74 \\
8 & Training in implementing critical thinking is a waste of time and effort for me. & 4.54 & 0.57 \\
9 & Using critical thinking in my instruction is beneficial. & 4.10 & 0.52 \\
10 & Discussing critical thinking integration with teachers is useless for me. & 4.37 & 0.69 \\
11 & I believe that critical thinking is the heart of the changes of the 21st century. & 4.17 & 0.57 \\
12 & I have no intention to integrate critical thinking in my class. & 4.45 & 0.67 \\
13 & I believe that future teachers must be prepared to be models of critical thinkers. & 4.28 & 0.60 \\
14 & I detest making use of critical thinking in my classroom. & 4.53 & 0.64 \\
15 & I prefer to see every learner in my class employing critical thinking skills. & 4.00 & 0.60 \\
16 & Critical thinking activities boost students' motivation. & 3.68 & 0.68 \\
17 & I encourage students to use critical thinking for solving problems. & 3.81 & 0.74 \\
18 & I am convinced of the value of critical thinking in education. & 4.26 & 0.57 \\
19 & I think that critical thinking skills must be encouraged inside the classroom and & 4.38 & 0.57 \\
& outside its walls. & & \\
20 & I believe that all learners should be taught to think critically. & 4.28 & 0.54 \\
\hline & Total Attitudes Mean & 4.12 & 0.33 \\
\hline
\end{tabular}

Scale: $\mathrm{SD}=$ Strongly Disagree, $\mathrm{D}=$ Disagree, $\mathrm{N}=$ Neutral, $\mathrm{A}=$ Agree, $\mathrm{SA}=$ Strongly Agree

\subsubsection{Items related to students}

As displayed in Table 2, with a high mean score of $(M=4.38 ; S D=0.57)$, teachers agreed with the statement "I think that critical thinking skills must be encouraged inside the classroom and outside its walls". Another highest mean $(\mathrm{M}=4.28 ; \mathrm{SD}=0.54)$ was recorded for the statement "I believe that all learners should be taught to think critically". Participants strongly agreed $(M=4.26 ; S D=0.57)$ with the statement "I am convinced of the value of critical thinking in education".

In the light of the provided information, it is essential to note that most of the 20 items had high mean scores. The overall mean of means score for this part was observed to be $(M=4.12)$ with an 
overall standard deviation of ( $\mathrm{SD}=0.33)$. Mean scores for these statements range from $(\mathrm{M}=4.54)$ and (3.54). The highest mean score ( $M=4.54)$ was observed for the statement "training in implementing critical thinking is a waste of time and effort for me", whereas the lowest mean score was observed for the statement "I enjoy traditional methods of the easy transfer of information". In the same line of thought, the highest standard deviation $(\mathrm{SD}=0.83)$ was detected for statement "I enjoy traditional methods of the easy transfer of information", whereas the lowest standard deviation (SD=0.49) was noted for the statement "I believe that critical thinking allows individuals to organize work".

\section{Discussion}

To determine teachers' attitudes towards the use of critical thinking in their classes, the respondents were asked to mark their level of agreement on a 5-point rating scale ranging from 1-Strongly disagree to 5-Strongly agree. Negative statements were reverse-coded before analysis was carried out. The mean score was found to be $M=4.12$, which suggested that teachers had positive attitudes towards critical thinking. This confirmed that teachers were ready to use critical thinking to help them enhance their teaching practices. Also, it indicated that teachers are aware that critical thinking can bring changes for better practices by providing a variety of learning opportunities for students. Positive attitudes of teachers may directly impact the success of involving students in critical thinking activities. This result is in compliance with the findings of Stapleton (2011) who conducted a survey on attitudes toward critical thinking among Hong Kong secondary school instructors. High school teachers were interviewed about their attitudes on the notion of critical thinking. The findings revealed that the respondents displayed strong approval for the integration of critical thinking in the curriculum while indicating a leaning for training in terms of how to teach critical thinking. Although many teachers believe critical thinking is an essential component in education, their lack of training leads to a lack of confidence to introduce it in their classes.

Asghatheidari and Tahriri (2015) found a similar pattern in their study when they examined 30 EFL teachers' attitudes towards critical thinking instruction in Iran using an attitude questionnaire. They acknowledged that the respondents had a rather clear idea of critical thinking. The teachers hold the belief that promoting critical thinking among students is an important burden on teachers. However, the majority of the participants reported that they need training in how to teach critical thinking in their classes.

Additionally, the finding of this research paper is relevant to the study by Ketabi, Zabihi, and Ghadiri (2013), in which they worked with 106 Iranian EFL teachers and tried to investigate language teachers' in-depth understanding of the importance of involving critical thinking as a crucial skill in the ELT curriculum. The findings revealed that language teachers viewed critical thinking as a pedagogical goal in English language classes. A similar finding was reported by Alazzi (2008) who conducted a qualitative study. The researcher interviewed high school social studies teachers concerning their attitudes on teaching critical thinking skills in their classes. The research findings revealed that Jordanian educators showed an immature understanding of the definition and teaching strategies of critical thinking. As mentioned in the review of the literature, teachers who have positive attitudes towards critical thinking are more willing to use critical thinking with their students. Nelson (2005) said that a critical thinking attitude is a basis for critical thinking that reflects an individual's engagement in a purposeful task.

\section{Directions for future research}

As with all studies, the findings brought about more possible areas that could be investigated in a distinctive way and with larger sample sizes in order to further strengthen the conclusions. Based on the results of this investigation, and taking into account the strengths and limitations of this study, the 
need for additional research concerning related problems became conspicuous. The suggested ideas for future studies may help in the progress of critical thinking in Moroccan high schools.

Hence, conducting a similar study using teachers from different subject matters can provide better information regarding teachers' critical thinking practice in Moroccan high schools. As for training, it was discovered that there were calls for training relaed to critical thinking on numerous occasions. Admittedly, the period of training could be an important variable in determining the effective integration of critical thinking in education. Therefore, the determination of an ideal length of the course is required. In other words, a study needs to be conducted to examine the question of how long it would take to train teachers to use critical thinking in their teaching. Besides, the government and its education department should offer the support that enables teachers to implement critical thinking in their lessons. A longitudinal study would also be useful for examining the performance of teachers in classrooms and difficulties hindering their use of critical thinking over the different years from Common Core to second-year Baccalaureate. This could help us understand the development of critical thinking over the three years in high school. Finally, the impact of teachers' age in implementing critical thinking in classrooms is an important finding which deserves more study.

\section{Conclusion and Implications}

This study sought to contribute to the literature investigating Moroccan English high school teachers' practice of critical thinking in their classrooms. The purpose of this section is to summarize findings and to discuss implications for practice. Responses were obtained from 423 high school teachers, who responded to the research survey. The findings showed that the teachers have a positive attitude towards critical thinking, leading to the conclusion that teachers' understanding of the classroom environment is of primary significance to enahance critical thinking in education.

The findings of the current study lead to several important theoretical implications related to the integration of critical thinking in Moroccan high schools. First, teachers' worries and misunderstandings about the integration of critical thinking in teaching should be minimized. Second, this humble work has the potential to make an important contribution in promoting critical thinking in Moroccan high schools. Third, communication among teachers in the institution where they work is vital. Teachers working together have a positive influence on each other. For effective teaching of critical thinking, it is essential for teachers to collaborate with their colleagues and discuss their ideas with them. Therefore, administrative staff should work hand in hand with teachers to facilitate teacher collaboration and face difficulties hindering them from working together and sharing ideas related to the integration of critical thinking. Finally, annual national or international critical thinking conferences should be organized in order to broaden teachers' knowledge of their students as learners and help them become critical thinkers.

\section{References}

Ajzen, I., \& Fishbein, M. (1980). Understanding attitudes and predicting social behavior. Englewood Cliffs, NJ: Prentice-Hall, Inc.

Alazzi, K. (2008). Teachers' perceptions of critical thinking: A study of Jordanian secondary school social studies teachers. The Social Studies, 99(6), 243.

Asgharheidari, F., \& Tahriri, A. (2015). A Survey of EFL teachers' attitudes towards critical thinking instruction. Journal of Language Teaching and Research, 6(2), 388-396. 
Benattabou, D. (2020). Helping EFL Students Avoid Socio-pragmatic Failure: Focus on Nonverbal Intercultural Competence. TESOL and Technology Studies, 1(1), 23-41.

Chouari, A. (2016). Teaching critical thinking in Moroccan Higher Education: challenges and opportunities. Arab World English Journal, 7, 2.

Choy, S. C., \& Cheah, P. K. (2009).Teacher perceptions of critical thinking among students and its influence on higher education. International Journal of Teaching and Learning in Higher Education, 20 (2), 198-206.

Creswell, J. W. (2012). Educational research: Planning, conducting, and evaluating quantitative and qualitative research (4th ed.). Upper Saddle River, NJ: Pearson Education.

Duron, R., Limbach, B., \& Waugh, W. (2006). Critical thinking framework for any discipline. International Journal of Teaching and Learning in Higher Education, 17(2), 160-166.

Eagly, A. \& Chaiken, S. H. (1993). The Psychology of Attitudes, New York: Harcourt Brace College Publishers.

Godin, G., Belanger-Gravel, A., Eccles, M., \& Grimshaw, J. (2008). Healthcare professionals' intentions and behaviours: A systematic review of studies based on cognitive theories. Implementation Science, 3, 36-48.

Halpern, D. (1989). Thought and Knowledge: An introduction to critical thinking. Hillsdale, NJ: Lawrence Erlbaum Associates.

Hamdy, A. (2007). Survey of ICT and education in Africa: Morocco country report. Washington, DC.: World Bank.

Hay, L. (2001). Thinking skills for the information age. In A. L. Costa (Ed.), Developing minds: A resource book for teaching thinking (3rd ed., pp. 7-10). Alexandria, VA: Association for Supervision and Curriculum Development.

Horwitz, E. K. (1989). Facing the blackboard: Student perceptions of language learning and the language classroom. ADFL Bulletin, 20(3), 61- 64.

Ibrahim, S., \& Ismail, F. (2021). University ESL Instructors' Reflections on the Use of Blended Learning in their Classrooms. TESOL and Technology Studies, 2(1), 25-35.

Ketabi, S., Zabihi, R. \& Ghadiri, M. (2013). Critical thinking accross the ELT curriculum: A mixed methods approach to analyzing L2 teachers' attitudes towards critical thinking instruction. International Journal of Research Studies in Education, 2(3), 15-24.

Khatib, M., Marefat, F., \& Ahmadi, M. (2012). Enhancing critical thinking abilities in EFL classrooms: Through written and audiotaped dialogue journals. Humanity \& Social Sciences Journal, 7(1), 33-45.

Kowalczyk, N. Hackworth, R \& Case-smith, J. (2012). Perception of the use of critical thinking methods. Radiologic technology, 83 (3), 226-237. 
Kumar, R. (2005) Research Methodology: A Step-By-Step Guide for Beginners, Thousand Oaks, CA: Sage Publications Ltd.

Latchanna, G. \& Dagnew, A. (2009). Atti-tude of teachers towards the use of active learning methods. E-journal of All India Association for Educational Research, 21(1).

McGuire, W. J. (1985) Attitudes and attitude change. In Lindzey, G. and Aronson, E. (Ed) Handbook of Social Psychology, New York: Random House.

Mok, J. (2010). The new role of English language teachers: Developing students' critical thinking in Hong Kong secondary school classrooms.Asian EFL journals, 12(2), 262287.

Nelson, J. (2005). Cultivating judgment: A sourcebook for teaching critical thinking. Stillwater, OK: New Forums Press.

Oates, B. J. (2006). Researching information systems and computing. London: SAGE.

Paul, R., \& Elder, L. (2009). Critical thinking concepts and tools. Dillon Beach, CA;Foundation for Critical Thinking.

Pellegrino, J. W., \& Hilton, M. L. (Eds.) (2012). Education for life and work: Developing transferable knowledge and skills in the 21st century. National Academies Press.

Qing, Z., Chungeng, Y., Shuyu, Z., Liya, L., \& Lijuan, X. (2012). A preliminary investigation into critical thinking of in-service and pre-service middle school chemistry teachers in Shaanxi province of China. Asia Pacific Forum On Science Learning \& Teaching, 13(2), 1-13.

Reid, N. (2003) Getting Started in Pedagogical Research in the Physical Sciences. LTSN Physical Sciences Practice Guide, Hull: LTSN.

Russell, D. H. (1956). Children's thinking. Boston: Ginn and Company Limited.

Sandy, L. D. (2010). Social capital, empowerment, and educational change: A scenario of permeation of one-to-one technology in schools. Journal of Computer Assisted Learning, 26(4), 284-295.

Stapleton, P. (2011). Survey of attitudes towards critical thinking among Hong Kong Secondary school teachers: Implications for policy change. Thinking Skills and Creativity 6, 14-23.

Tarman, B. (2012). Prospective Teachers' Beliefs and Perceptions about Teaching as a Profession. Educational Sciences: Theory \& Practice, 12(3), 1964-1973.

Wagner, T. (2008). The global achievement gap: Why even our best schools don't teach the new survival skills our children need and what we can do about it. New York, NY: Basic Books.

Zohar, A., \& Dori, Y. J. (2003). Higher order thinking skills and low-achieving students: Are they mutually exclusive? Journal of the Learning Sciences, 12(2), 145-181. 